\title{
GAMBARAN FAKTOR-FAKTOR YANG MEMPENGARUHI SUAMI DALAM MEMBERIKAN DUKUNGAN KB TUBEKTOMI PADA IBU
}

\author{
Lia Alfa Shaliha'), Uswatun Kasanah' ${ }^{2)}$, Sifa Altika ${ }^{3)}$ \\ ${ }^{1,2}$ Prodi Sarjana Kebidanan, Stikes Bakti Utama Pati \\ ${ }^{3}$ Prodi Diploma Tiga Kebidanan, Stikes Bakti Utama Pati \\ Email: haqqacantiq@gmail.com
}

\begin{abstract}
ABSTRAK
Keluarga kecil yang berkualitas dapat diawali dengan adanya jumlah dan jarak kehamilan yang sehat. Untuk mengatur jumlah anak tersebut diperlukan alat kontrasepsi. Metode kontrasepsi tubektomi merupakan salah satu metode kontrasepsi yang paling efektif dan aman. Tubektomi tidak mencapai angka yang maksimal, untuk itu diperlukan dukungan suami agar metode kontrasepsi tersebut diminati masyarakat. Penelitian ini merupakan studi deskriptif dengan pendekatan cross sectional, yang bertujuan mengetahui faktor-faktor yang mempengaruhi suami dalam memebrikan dukungan tubektomi istri. Teknik pengambilan sampel dengan total sampling sebanyak 34 responden di wilayah Puskesmas Kradenan II. Data primer diperoleh dari penyebaran kuesioner. Data sekunder diperoleh medical record atau catatan medis. Analisis data univariat yaitu menganalisa Variabel secara diskriptif dengan menghitung distribusi frekuensi dan proporsinya untuk mengetahui karakteristik dari suatu obyek. Dari hasil penelitian didapatkan bahwa responden yang berumur 30-40 tahun sebanyak $23,5 \%$, umur 41-50 tahun sebanyak 47,05\%, dan umur 51-60 29,4\%, responden yang tidak tamat SD sebayak $8,82 \%$, SD sebanyak 14,7\%, SMP atau Mts atau sederajat 44,12\%, SMA 29,41\%, Perguruan Tinggi sebanyak 2,94\% responden dengan Paritas Multipara 52,94\% dan Grandemultipara sebanyak $47,06 \%$, responden yang bekerja sebagai PNS sebanyak 17,960\%, swasta $32,35 \%$, buruh $8,82 \%$, petani $17,60 \%$, pedagang $23,50 \%$. Responden yang memiliki tingkat pengetahuan baik sebanyak $58,82 \%$, cukup sebesar $35,29 \%$, kurang sebesar $5,88 \%$. Responden yang bersikap positif tentang pemilihan metode MOW sebesar $88,23 \%$ dan bersikap negatif sebesar $11,77 \%$. Responden dengan budaya sosial rendah sebanyak $29,41 \%$ dan sosial budaya sedang $55,88 \%$ sosial budaya tinggi $14,71 \%$. Saran : bagi tenaga kesehatan kususnya bidan diharapkan lebih meningkatkan pelaksanaan Komunikasi, Informasi, Edukasi (KIE) mengenai kontrasepsi kontrasepsi tujuan, manfaat, indikasi, kontraindukasi, dan macam-macam metode kontrasepsi.
\end{abstract}

Kata kunci : dukungan suami, KB tubektomi istri

\section{ABSTRACT}

A quality small family can be started by having a healthy number and spacing of pregnancies. To regulate the number of children, contraception is needed. The tubectomy method of contraception is one of the most effective and safe contraceptive methods. Tubectomy does not reach the maximum number, for this reason, husband's support is needed so that this method of contraception is in demand by the public. This research is a descriptive study with a cross sectional approach, which aims to determine the factors that influence the husband in providing support for his wife's tubectomy. The sampling technique with a total sampling of 34 respondents in the Kradenan II Health Center area. Primary data obtained from the distribution of questionnaires. Secondary data obtained from medical records or medical records. Univariate data analysis is analyzing variables descriptively by calculating the frequency distribution and its proportions to determine the characteristics of an object. From the results of the study, it was found that $23.5 \%$ of respondents aged 30-40 years old, $41-50$ years old were 47.05\%, and 51-60 years old 29.4\%, respondents who did not finish elementary school were $8.82 \%$, Elementary school as much as $14.7 \%$, SMP or MTs or equivalent $44.12 \%$, SMA $29.41 \%$, Universities as many as $2.94 \%$ of respondents with Paritas Multipara 52.94\% and Grandemultipara as many as $47.06 \%$, respondents who work as $17.960 \%$ civil servants, $32.35 \%$ private, $8.82 \%$ workers, $17.60 \%$ farmers, $23.50 \%$ traders. Respondents who have a good level of knowledge are $58.82 \%$, $35.29 \%$ is sufficient, less is $5.88 \%$. Respondents who have a positive attitude about the selection of the MOW method are $88.23 \%$ and negative attitudes are $11.77 \%$. Respondents with a low socio-cultural as much as $29.41 \%$ and a medium socio-cultural $55.88 \%$ high socio-cultural $14.71 \%$. Suggestion: for 
health workers, especially midwives, it is expected to further improve the implementation of Communication, Information, Education (KIE) regarding contraceptive purposes, benefits, indications, contra-induction, and various contraceptive methods.

Keywords: husband's support, wife's tubectomy family planning

\section{PENDAHULUAN}

Partisipasi suami menjadi salah satu faktor dalam mensukseskan program kesehatn reproduksi penggunaan alat kontrasepsi terlebih bagi pasutri (pasangan suami istri adalah tanggunag jawab bersama antara pria dan wanita, sehingga metode yang dipilih mencerminkan kebutuhan serta keinginan suami istri tanpa mengesampingkan hak reproduksi masing-masing ( Mutiara, 2010).

Upaya meningkatkan persepsi melalui promosi KB dengan berbagai median dan bentuk diharapkan akan menumbuhkan persepsi yang benar pada masyarakat terutama pria sehingga mereka sadar dan dengan ihklas ikut serta menjadi peserta $\mathrm{KB}$ berkelanjutan memang harus dilakukan, meningkatkan persepsi dan pemikiran yang salah tentang $\mathrm{KB}$ (BKKBN, 2011)

Menurut Hartanto (2011) Program KB juga berpotensi menyelamatkan kehidupan melalui cara mengikutsertakan wanita untuk ikut merencanakan kapan mengalami kehamilan, kapan harus mengatur jarak persalinan, dan kapan harus berhenti mempunyai anak.

Untuk mengatur jumlah anak ini diperlukan alat kontrasepsi. Metode kontrasepsi yang ditawarkan pemerintah ada bermacammacam yaitu pil, suntikan, kondom, alat kontrasepsi dalam rahim (AKDR), susuk, dan tubektomi atau lebih dikenal dengan sterilisasi. Dari semua macam kontrasepsi yang paling ideal, memang tidak ada karena harus disesuaikan dengan kondisi calon akseptor, tapi dari semua metode kontrasepsi tubektomi merupakan metode yang paling efektif dan aman.

Kontrasepsi mantap Tubektomi adalah suatu cara kontrasepsi permanen baik pada pria atau wanita, dilakukan dengan tindakan operasi kecil untuk mengikat atau menjepit atau memotong saluran telur (perempuan) atau menutup saluran mani (laki-laki), sehingga sperma tidak dapat bertemu dengan ovum (Hartanto, 2014). Metode ini dikatakan efektif karena banyak keuntungan antara lain sangat aman karena angka kegagalan sangat rendah 0,2 - 4 kehamilan per 100 perempuan, selama tahun pertama penggunaan permanen tidak menghambat produksi ASI, tidak ada efek samping (Saifudin, 2015). Dalam program KB, salah satu masalah yang dihadapi saat ini adalah masih rendahnya penggunaan Metode Kontrasepsi Jangka Panjang, yaitu kontrasepsi tubektomi. Berdasarkan Survei Demografi Kesehatan Indonesia (SDKI), peserta KB tubektomi sempat mengalami peningkatan sebesar 3,7\% (SDKI 2002/03) dari 56,6\% akseptor KB, namun kembali turun menjadi 3\% (SDKI 2007). Padahal salah satu sasaran strategis di bidang KB yang harus dicapai oleh BKKBN sampai dengan tahun 2014 dalam rangka pencapaian penurunan Laju Pertumbuhan Penduduk menjadi $1,1 \%$, Total Fertility Rate (TFR) menjadi 2,1, Net Reproductive Rate (NRR) $=1$, unmet need 5\%, dan Contraceptive Prevalence Rate (CPR) 65\% salah satunya adalah meningkatnya persentase peserta KB aktif MKJP khususnya tubektomi yaitu 27,5\% (Witjaksono, 2012) Sterilisasi (tubektomi) merupakan salah kontrasepsi yang paling efektif. Keefektifan metode sterilisasi mencapai $98,85 \%$ bila dilakukan sesuai dengan standar operasional prosedur yang telah ditetapkan. Tubektomi memiliki keuntungan karena keluhan lebih sedikit dibandingkan dengan cara kontrasepsi yang lain. Selain itu kontrasepsi ini juga lebih praktis karena hanya memerlukan satu kali tindakan saja (Endang Purwoastuti, 2015) Di dalam pelaksanaan program, animo masyarakat terhadap sterilisasi sangat kurang. Peserta sterilisasi sejak program KB dicanangkan pada tahun 1970 hingga saat ini masih menunjukkan angka yang sangat sedikit (BKKBN, 2011) Pemilihan alat kontrasepsi dapat dipengaruhi oleh beberapa karakteristik akseptor KB seperti pendidikan, tingkat pengetahuan, pekerjaan, sikap, umur, 
jumlah anak (paritas), dukungan suami, dan ekonomi (Dewi, 2013) Berdasarkan penelitian (Kristina, I, 2013) tentang faktor-faktor yang berpengaruh terhadap rendahnya minat dalam menggunakan kontrasepsi tubektomi didapatkan ada pengaruh signifikan antara motivasi, pengetahuan, sikap dan dukungan suami terhadap minat PUS dalam menggunakan kontrasepsi tubektomi. Berdasarkan fenomena diatas, menunjukkan bahwa ada beberapa faktor yang berhubungan dengan pemilihan alat kontrasepsi tubektomi antara lain pengetahuan dan dukungan suami. Sehingga peneliti tertarik ingin melakukan penelitian yang bertujuan untuk mengetahui "Hubungan Pengetahuan dan Dukungan Suami Terhadap Pemilihan Kontrasepsi Tubektomi di Pekanbaru Tahun 2016"

Dalam memilih metode ini ibu dan suami perlu mendapatkan konseling atau penjelasan yang benar dan lengkap dari petugas kesehatan, hal ini mengharuskan petugas kesehatan mempunyai sumber daya manusia harus yakin dan mengetahui secara pasti itu tubektomi sebelum mengambil keputusan mulai dari tahap mengetahui, tertarik, kemudian menilai lalu mencoba baru setelah itu menerima (IBI, 2014).

Dari data UPTD (Unit Pelaksana Teknis Badan) Pemberdayaan Perempuan, Perlindungan Anak, dan KB Kecamatan Kradenan Kabupaten Grobogan bulan Desember 2008 tercatat peserta KB Aktif KB aktif sebanyak 12.357 orang $(78,96 \%)$ dari 15.648 PUS yang ada, adapun jumlah dan persentase pemakaian masing-masing alat kontrasepsi adalah suntik sebanyak 7424 (47, 44\%), Pil sebanyak 1981 orang $(12,66 \%)$, implant sebanyak 265 orang (1,693\%), MOW 367 orang $(2,345 \%)$, IUD sebanyak 2.126 orang $(13,59 \%)$, kondom 183 orang $(1,169 \%)$, MOP 11 orang $(0,070 \%)$. (UPTD PP,PA, dan KB Kecamatan Kradenan, Desember 2018).

Di Desa Kalisari jumlah peserta KB aktif sampai dengan bulan Desember 2008 sebanyak 1.074 orang $(125,76 \%)$ dari PUS sebanyak 854 orang. Suntik sebanyak 465 orang $(54,45 \%)$, pil sebanyak 118 orang $(22,01 \%)$, MOW sebanyak 12 orang $(1,405 \%)$, implant sebanyak 2 orang $(0,243 \%)$, IUD sebanyak 243 orang $(28,54 \%)$,
MOP tidak ada, dan kondom sebanyak 14 orang $(1,639 \%)$ (UPTD PPA, PA, dan KB Kecamatan Kradenan, Desember 2018).

Pemakaian tubektomi di wilayah kerja Puskesmas Kradenan II Kabupaten Grobogan sampai bulan Desember 2019 yang paling tinggi adalah Desa Bago 76 akseptor dan yang paling rendah adalah Desa Tanjungsari sebanyak 9 akseptor (Puskesmas Kradenan II, 2019). Angka pencapaian tubektomi masih kurang dibandingkan dengan alat kontrasepsi lainnnya. Padahal tubektomi merupakan suatu KB yang paling efektif dibandingkan seluruh cara yang tersedia. Keefektifannya tercapai begitu operasi selesai dikerjakan (UPTD PPI, dan KB Kecamatan Kradenan Desember 2019).

Survei pendahuluan yang dilakukan di desa Kalisari Kecamatan Kradenan pada 30 responden, diketahui bahwa ibu yang tahu tujuan, manfaat, efek samping kontrasepsi sebanyak 23 orang $(76,67 \%)$ dan yang tidak tahu sebanyak 7 orang $(23,33 \%)$. Dari 30 responden yang mendapat dukungan dukungan suami sebanyak 25 orang $(83.23 \%)$ dan yang tidak mendapat dukungan sebanyak 5 orang $(16,67 \%)$.

Pengetahuan yang didapat melalui pendidikan formal maupun nonformal serta didapat dari pergaulan sehari-hari dengan orang lain, media informasi, penyuluhan di posyandu serta sumber informasi lain sebagai dasar untuk bertindak. Semakin baik pengetahuan seseorang akan semakin baik untuk menerapkan perilaku kesehatan dalam hal ini pngetahuan tentang kontrasepsi sebagai dasar untuk memilih kontrasepsi tubektomi. Perilaku yang berdasarkan pengetahuan akan lebih langgeng daripada perilaku yang tidak didasari pengetahuan. ( Notoatmodjo, 2013).

Sebagai salah satu metode kontrasepsi yang paling efektif dan aman, tubektomi tidak mendapat pencapaian angka yang maksimal. Tujuan umum penelitian ini adalah untuk mengetahui gambaran faktor-faktor yang mempengaruhi suami dalam memberikan dukungan KB tubektomi pada istri. Adapun tujuan khususnya adalah untuk mendiskripsikan gambaran pengetahuan suami, pendidikan 
suami, usia suami, jumlah anak suami, sikap suami, sosial budaya suami, pekerjaan suami.

Jenis penelitian yang digunakan adalah penelitian diskriptif dengan metode pendekatan cross sectional.

\section{METODE}

Jenis penelitian yang digunakan dalam penelitian ini adalah diskriptif. Metode penelitian yang digunakan dalam penelitian ini adalah survei dengan pendekatan cross sectional. Variabel independen adalah faktor pendidikan, jumlah anak, pekerjaan, pengetahuan tentang KB tubektomi, sikap dan sosial budaya, sedangkan variabel dependen adalah dukungan suami terhadap KB tubektomi. Populasi dan sampel dalam penelitian adalah suami dari seluruh responde $\mathrm{KB}$ tubektomi sebanyak 34 orang berada di wilayah puskesmas Kradenan II Kab. Grobogan sejumlah 34 orang yang diambil dengan teknik total sampling. Instrumen yang digunakan dalam bentuk kuesioner. Kuisioner terdiri dari 22 pertanyaan.

\section{HASIL}

1. Faktor Pengetahuan Suami

Tabel 1.

Distribusi Frekuensi Tingkat Pengetahuan Suami $(n=34)$

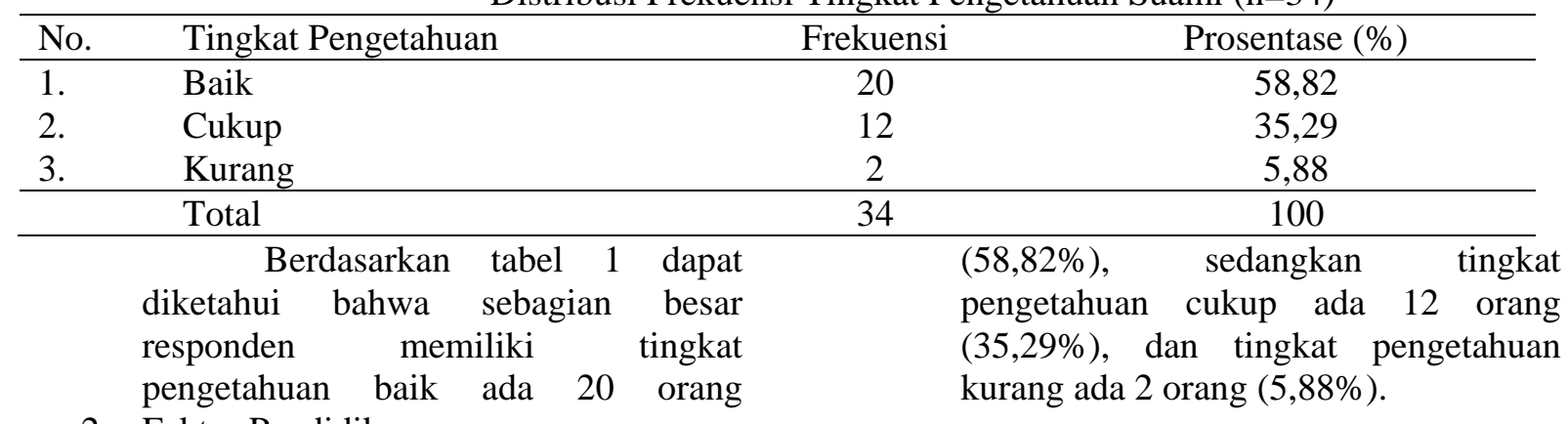

2. Faktor Pendidikan

Tabel 2.

Distribusi Frekuensi Tingkat Pendidikan Suami $(n=34)$

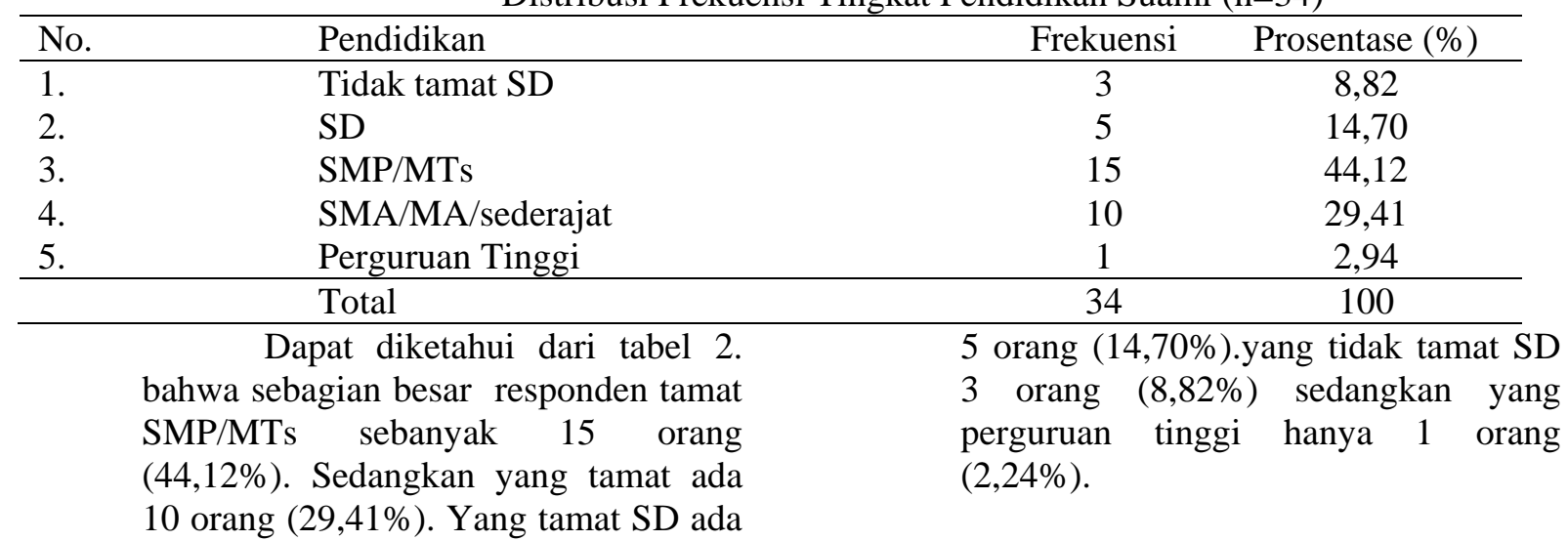

3. Faktor Usia

Tabel 3.

Distribusi Frekuensi Tingkat Usia Suami $(\mathrm{n}=34)$

\begin{tabular}{llcc}
\hline No. & Umur & Frekuensi & Prosentase $(\%)$ \\
\hline 1. & $30-40$ tahun & 8 & 23,5 \\
2. & 41-50 tahun & 16 & 47,05 \\
3. & 51- 60 tahun & 10 & 29,4 \\
\hline & Total & 34 & 100 \\
\hline
\end{tabular}


Menurut tabel 3 sebagian besar responden berusia antara usia 41-50 tahun ada 16 orang $(47,05 \%)$, usia 51 -
60 tahun ada 10 orang $(29,4 \%)$, dan umur $30-40$ tahun ada 8 orang $(23,5 \%)$.

4. Faktor Jumlah anak

Tabel 4.

Distribusi Frekuensi Tingkat Jumlah Anak ( $\mathrm{n}=34)$

\begin{tabular}{llccl}
\hline No. & \multicolumn{1}{c}{ Paritas } & Frekuensi & Prosentase $(\%)$ \\
\hline 1. & Multipara & 18 & 52,94 & \\
2. & Grandemultipara & 16 & 47,06 & 100 \\
\hline \multicolumn{6}{c}{ Total } & 34 & $(52,94 \%)$, grandemultipara ada & 16 \\
& Dapat diketahui dari tabel 4. & orang $(47,06 \%)$. & &
\end{tabular}

5. Faktor Sikap

Tabel 5 .

Distribusi Frekuensi Tingkat Sikap Suami $(n=34)$

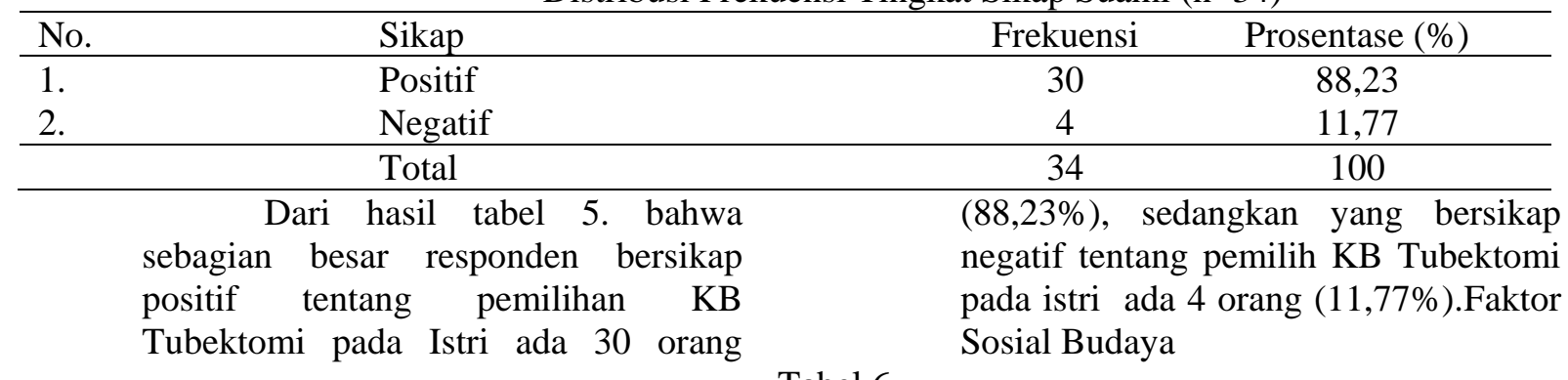

Tabel 6.

Distribusi Frekuensi Tingkat Sosial Budaya Suami $(n=34)$

\begin{tabular}{|c|c|c|c|}
\hline No. & Sosial Budaya & Frekuensi & Prosentase $(\%)$ \\
\hline 1. & Mendukung & 10 & 29,41 \\
\hline 2. & Kurang mendukung & 19 & 55,88 \\
\hline \multirow[t]{2}{*}{3.} & Tidak mendukung & 5 & 14,71 \\
\hline & Total & 34 & 100 \\
\hline & $\begin{array}{l}\text { arkan tabel } 6 \text { sebagian } \\
\text { an dengan tingkat sosial } \\
\text { ang mendukung ada } 19 \\
8 \% \text { sosial budaya }\end{array}$ & $\begin{array}{l}\text { mendukun } \\
\text { sedangkat } \\
\text { yang tida } \\
(14,71 \%) .\end{array}$ & $\begin{array}{l}10 \text { orang, }(29,41 \%) \text {, } \\
\text { tingkat sosial budaya } \\
\text { ndukung ada } 5 \text { orang }\end{array}$ \\
\hline
\end{tabular}

6. Faktor Pekerjaan

Tabel 7.

Distribusi Frekuensi Tingkat Pekerjaan Suami $(n=34)$

\begin{tabular}{llcc}
\hline No. & Pekerjaan & Frekuensi & Prosentase $(\%)$ \\
\hline 1. & PNS & 6 & 17,60 \\
2. & Karyawan Swasta & 11 & 32,35 \\
3. & Buruh & 3 & 8,82 \\
4. & Petani & 6 & 17,60 \\
5. & Pedagang & 8 & 23,50 \\
\hline & Total & 34 & 100 \\
\hline
\end{tabular}


Dalam tabel 7. sebagian besar responden bekerja karyawan swasta ada 11 orang $(32,35 \%)$, Pedagang ada 8 orang $(23,50 \%)$, Petani ada 6 orang $(17,6 \%)$,Sama halnya dengan PNS ada 6 orang $(17,6 \%)$, dan paling kecil Buruh ada 3 orang $(8,82 \%)$.

\section{PEMBAHASAN}

a. Pengetahuan Suami tentang KB Tubektomi

Berdasarkan hasil penelitian, responden yang memiliki pengetahuan baik ada 20 orang $(58,82 \%)$, pengetahuan cukup ada 12 orang (35,29\%), pengetahuan kurang ada 2 orang $(5,88 \%)$. Pengetahuan atau kognitif dapat diperoleh dari proses pengalaman dan proses belajar baik pendidikan formal maupun non formal. Pengetahuan diibaratkan sebagai alat yang dipakai manusia dalam menyelesaikan persoalan yang dihadapi (Notoatmodjo, 2013).

Tingkat pengetahuan dikatakan baik, cukup, kurang diawali dari mengetahui,

mengaplikasikan, memahami, mensintesis dan terakhir mengevaluasi. Responden mengetahui tentang kontrasepsi Medis Operatif Wanita dari penjelasan petugas kesehatan. Semua responden mengikuti penyuluhan kesehatan tentang KB Tubektomi dari petugas kesehatan. Guna mengetahui tingkat pemahaman responden, dilakukan evaluasi secara lisan menggunakan kuesioner oleh peneliti.

Dari 34 orang responden, yang mengatakan mengetahui pengertian, tujuan, cara operasi KB Tubektomi ada 4 orang, mengetahui manfaat dan efek samping KB Tubektomi ada 11 orang. 6 orang mengetahui manfaat, tetapi mengatakan takut menghadapi operasi KB Tubektomi. 13 orang mengetahui pengertian, manfaat dan efek samping. Seluruh responden mengatakan memilih KB Tubektomi.

Hasil penelitian ini sejalan dengan penelitian yang dilakukan oleh Nurul Hidayah. (2019) dengan judul "Hubungan Pengetahuan dan Dukungan Suami Terhadap Pemilihan Kontrasepsi Tubektomi”, yang mana hasil penelitian diperoleh Hasil penelitian diperoleh Pengetahuan (Pvalue $=0,021$ ) dan dukungan suami (Pvalue=0,000). Hasil ini menunjukkan ada hubungan pengetahuan dan dukungan suami terhadap pemilihan kontrasepsi tubektomi. Di harapkan bagi pihak Puskesmas untuk meningkatkan promosi, konseling dan penyuluhan kesehatan guna meningkatkan pengetahuan ibu dan suami tentang kontrasepsi tubektomi.

b. Pendidikan Suami

Hasil penelitian menunjukkan bahwa sebagian besar responden yang tamat MMP/MTs sebanyak 15 orang $(44,12 \%)$. Sedangkan yang tamat ada 10 orang $(29,41 \%)$. Yang tamat SD ada 5 orang $(14,70 \%)$.yang tidak tamat SD 3 orang $(8,82 \%)$ sedangkan yang perguruan tinggi hanya 1 orang $(2,24 \%)$.

Pada awal pernikahan, semua responden yang sekolah, belum menganggap bahwa perlu perencanaan jumlah anak. Yang penting sekolah, bekerja kemudian menikah dan memiliki keturunan. Yang tidak sekolah mengatakan bahwa yang penting bisa bekerja, mencari nafkah, kemudian menikah. Responden mengatakan bahwa memiliki keturunan adalah salah satu tujuan menikah, karena anak adalah generasi penerus.

Pendidikan secara umum adalah segala upaya yang direncanakan untuk mempengaruhi orang lain baik individu, kelompok atau masyarakat sehingga mereka melakukan apa yang diharapkan oleh pelaku pendidikan. Pendidikan dipengaruhi oleh banyak hal. Salah satunya adalah sumber informasi dan media informasi, baik media cetak, elektronik maupun tenaga kesehatan (Notoatmodjo, 2013).

Tingkat pendidikan seseorang berpengaruh dalam memberikan respon terhadap sesuatu yang datang dari luar. Pendidikan formal akan membantu seseorang untuk memperoleh pengetahuan, pemahaman serta nilai-nilai lainnya yang akan membantu yang bersangkutan untuk berfikir secara rasional. Seseorang yang berpendidikan 
tinggi akan lebih mudah menerima dan mampu memahami pesan atau informasi dibandingkan dengan yang tidak berpendidikan.

Semakin tinggi pendidikan, semakin mudah memahami informasi tentang kesehatan. Sehingga semakin rendah tingkat pendidikan, semakin sulit menyerap informasi tentang kesehatan (Notoatmodjo, 2013). Sebelum memilih metode kontrasepsi KB Tubektomi, responden pendidikan SD berpendapat bahwa memang benar "banyak anak banyak rejeki", tetapi mencari uang semakin sulit, kebutuhan bertambah. Responden lain mengatakan bahwa penting sekali melakukan perencanaan keluarga, demi masa depan yang lebih baik.

Hasil penelitian ini sejalan dengan penelitian yang dilakukan oleh Susi Ernawati. (2016) dengan judul "Faktor yang Memengaruhi Keluarga Berencana (KB) Pria dengan Paritisipasi Pria dalam Keluarga Berencana di Wilayah Kerja Puskesmas", hasil penelitian menunjukkan bahwa pendidikan responden pria dalam penelitian ini sebagian besar berpendidikan tamat SLTA/SMK yaitu sebanyak 41 orang $(65,1 \%)$. Berdasarkan tabel 4 diketahui bahwa jumlah responden yang berpendidikan tidak tamat SD 1 orang $(1,6 \%)$, tamat SD 4 orang $(6,3 \%)$, tamat SLTP 15 orang $(23,8 \%)$, tamat SLTA/SMK 41 orang $(65,1 \%)$, dan tamat perguruan tinggi 2 orang $(3,2 \%)$.

c. Usia suami

Hasil penelitian terhadap 34 orang menunjukkan bahwa sebagian besar responden dari usia 41-50 tahun ada 16 orang $(47,05 \%)$, usia 51-60 tahun ada 10 orang $(29,4 \%)$, dan umur 30-40 tahun ada 8 orang $(23,5 \%)$.

\section{d. Jumlah responden}

Seluruh responden rata-rata dalam keadaan sehat, tidak memiliki penyakit menurun menular atau menurun (DM, hipertensi, jantung,dll ).

Sebagai kepala rumah tangga, responden adalah penentu keputusan di dalam keluarga. Penentu keputusan tidak berarti bahwa keputusan diambil tanpa musyawarah dengan suami. Sebagian besar suami responden dapat menerima keputusan yang telah di pilih. Menurut responden, suami mereka menyadari bahwa dengan bertambahnya usia, dan dengan memperhatikan kondisi fisik, penentuan jumlah anak sangat penting karena demi masa depan anak.

Hasil penelitian ini sejalan dengan penelitian yang dilakukan oleh Yuli Suryanti, (2019). dengan judul "FaktorFaktor Yang Berhubungan Dengan Penggunaan Metode Kontrasepsi Jangka Panjang Wanita Usia Subur", hasil penelitian menunjukkan Ada hubungan umur dengan penggunaan MKJP dengan p-value $(0,000)<0,05$. Ada hubungan partisipasi suami dengan penggunaan MKJP dengan p-value $(0,000)<0,05$.

e. Jumlah Anak

Hasil penelitian pada 34 responden menunjukkan bahwa responden memiliki 2-5 anak ada 18 orang (52,94\%), 6 anak ada 16 orang $(47,06 \%)$.

Berdasarkan hal diatas, sebagian besar responden $(52,94 \%)$ sudah memiliki 2 orang anak atau lebih, yang memiliki anak lebih dari 5 orang ada 16 orang $(47,06 \%)$. Bertambahnya jumlah anak, beban hidup semakin berat. Tanggung jawab menghidupi keluarga, perencanaan pendidikan anak dan masa depan keluarga menjadi Pengalaman menghidupi keluarga, memenuhi kebutuhan anak dan istri, semakian memperkuat responden membuat keputusan tentang berapa jumlah anak yang harus dimiliki.

Keputusan memilih metode kontrasepsi dilakukan dengan cara musyawarah dengan suami. Akhirnya responden memilih metode kontrasepsi MOW.

Hasil penelitian ini sejalan dengan penelitian yang dilakukan oleh Vida Wira Utami, (2014), dengan judul "Faktor Faktor Yang Mempengaruhi Penggunaan Vasektomi Di Kota Bandar Lampung", dan hasil penelitian pada analisis bivariat menunjukan adanya hubungan yang 
bermakna antara pengetahuan terhadap penggunaan vasektomi $(\mathrm{p}$ value $=0.006$, $\mathrm{OR}=2,742)$, sikap terhadap penggunaan vasektomi $(\mathrm{p}$ value $=0.000, \mathrm{OR}=3,880$ ), pendidikan terhadap penggunaan vasektomi $(\mathrm{p}$ value $=0.059, \mathrm{OR}=2,902$ ), jumlah anak terhadap penggunaan vasektomi $(\mathrm{p}$ value $=0.129, \mathrm{OR}=0,564$ ), pekerjaan terhadap penggunaan vasektomi ( $\mathrm{p}$ value $=0.791, \mathrm{OR}=0,753)$, dukungan istri terhadap penggunaan vasektomi $(\mathrm{p}$ value $=0.000, \mathrm{OR}=$ 20,364). Dari analisis multivariat faktor yang paling dominan mempengaruhi penggunaan vasektomi adalah dukungan istri dengan $\mathrm{p}$-value $=0,000, \mathrm{OR}=$ 20,364 dan CI 95\% = 8,048 - 51,526.

\section{f. Sikap Suami}

Berdasarkan hasil penelitian, responden yang bersikap positif tentang pemilih KB Tubektomi ada 31 orang (91,17\%), yang bersikap negatif tentang pemilih KB Tubektomi ada 3 orang $(8,83 \%)$.

Menurut Azwar (2013), orang lain sekitar individu yaitu seseorang yang dianggap penting, seseorang yang diharapkan persetujuan bagi tindakan dan pendapat, seseorang yang tidak ingin dikecewakan atau seseorang yang berarti khusus bagi individu akan mempengaruhi pembentukan sikap individu Sikap memilih KB Tubektomi ini dilakukan setelah respon mendapat penjelasan dari petugas kesehatan. Hal ini menunjukkan bahwa tindakan petugas kesehatan sangat bermanfaat dan mampu memicu keputusan responden dalam memilih metode kontrasepsi.

Hasil penelitian ini sejalan dengan penelitian yang dilakukan oleh Rosnitje Mangeto, (2019), dengan judul "Gambaran Pengetahuan, Sikap Dan Tindakan Akseptor KB Terhadap Tindakan Tubektomi Di Puskesmas Kassi-Kassi Makassar Tahun 2019", hasil penelitian menunjukan bahwa dari 80 Akseptor KB yang menggunakan kontrasepsi berdasarkan umur 20-35 tahun yaitu 57 orang $(71,25 \%)$ dan $>35$ tahun dan $<40$ tahun yaitu sebanyak 23 orang $(28,75 \%)$, SD yaitu 10 orang
(12,5\%), SMP yaitu 14 orang $(17,5 \%)$, SMA yaitu 46 orang $(57,5 \%)$ dan S1 yaitu 10 orang $(12,5 \%)$, IRT yaitu 55 orang $(68,75 \%)$, Wiraswasta yaitu 15 orang $(18,75 \%)$ dan PNS 10 orang $(12,5 \%)$, Suntikan 45 orang $(56,25 \%)$, PIL yaitu 30 orang $(37,5 \%)$ dan Tubektomi yaitu 5 orang $(6,25 \%)$ dan baik yaitu 30 orang $(37,5 \%)$, kurang yaitu 50 orang $(62,5 \%)$ dan positif yaitu 70 orang $(87,5 \%)$, negatif yaitu 10 orang $(12,5 \%)$ dan tepat yaitu 63 orang ( $78,8 \%$ ), tidak tepat yaitu 17 orang $(20,3 \%)$.

g. Faktor Sosial Budaya

Hasil penelitian menunjukkan bahwa responden dengan sosial budaya kurang mendukung ada 19 orang $(29,41 \%)$, social budaya mendukung ada 10 orang $(55,88 \%)$, sosial budaya tidak mendukung ada 5 orang $(14,71 \%)$. Latar belakang budaya mempengaruhi keyakinan, nilai dan kebiasaan individu.

Budaya juga mempengaruhi tempat masuk ke dalam system pelayanan kesehatan dan mempengaruhi cara melaksanakan kesehatan pribadi. Pembuatan keputusan oleh responden dipengaruhi oleh suatu budaya yang sangat mementingkan nilai dan hubungan keluarga yang dekat, hangat dan supportif.

Tidak adanya perbedaan suku dan ras di desa Kalisari Kecamatan Kradenan Kabupaten Grobogan mendukung suasana kekeluargaan dalam pengambilan keputusan KB Tubektomi. Perbedaan agama tidak menjadi masalah dalam hidup bermasyarakat. Responden bisa memahami keyakinan masing-masing.

Hasil penelitian tersebut diatas sejalan dengan penelitian yang dilakukan oleh Fitra Sawiyya Sufiati, (2011) dengan judul "Faktor Faktor Yang Berhubungan Dengan Pemilihan Metode Kontrasepsi Tubektomi Pada Pasangan Usia Subur", Hasil penelitian ini menunjukkan bahwa Ada hubungan antara sosial budaya (Kepercayan) dengan pemilihan kontrasepsi tubektomi pada pasangan usia subur, dimana responden yang memilih tubektomi sosial budaya (kepercayaan) 
tidak melarang sebesar 44 responden $(66,7 \%)$ di banding yang memiliki social budaya (kepercayaan) melarang 22 responden $(33,3 \%)$.

h. Pekerjaan

Berdasarkan hasil penelitian pada 34 responden, menunjukkan bahwa responden yang bekerja sebagaian besar responden yang bekerja Swasta ada 11 orang $(32,35 \%)$, Pedagang ada 8 orang $(23,50 \%)$, Petani ada 6 orang $(17,6 \%)$,Sama halnya dengan PNS ada 6 orang $(17,6 \%)$, dan paling kecil Buruh ada 3 orang $(8,82 \%)$.

Perbedaan jenis pekerjaan responden secara langsung maupun tidak langsung mempengaruhi tingkat pendapatan. Tingkat pendapatan yang berbeda-beda membuat seseorang memiliki pola pikir berbeda pula karena menyesuaikan dengan biaya hidup yang semakin tinggi.

Bagi responden yang bekerja sebagai PNS, maupun yang bekerja sebagai buruh, petani dan pedagang, pemilihan KB Tubektomi bertujuan untuk menjamin tingkat pendidikan anak dan masa depan keluarga.

Hasil penelitian ini sejalan dengan penelitian yang dilakukan oleh Nurul Farahan, (2016) dengan judul "Gambaran Tingkat Pengetahuan Penggunaan Alat Kontrasepsi Pada Wanita Usia Subur Dan Dukungan Petugas Di Desa Bebandem Kabupaten Karangasem Bali Tahun 2014", hasil penelitian menunjukkan bahwa pekerjaan responden, pada responden yang tidak bekerja, lebih banyak (56.1\%) yang menggunakan KB daripada yang tidak menggunakan KB. Pada responden yang bekerja, kebanyakan (55.1\%) telah menggunakan KB. Dilihat dari karakteristik tingkat penghasilan responden, pada responden yang memiliki penghasilan keluarga rendah, sebagian besar (66.7\%) tidak menggunakan KB. Pada responden yang berpenghasilan menengah rendah, lebih banyak responden $(57.8 \%)$ yang telah menggunakan $\mathrm{KB}$ dibandingkan yang tidak menggunakan KB. Sementara pada responden yang memiliki penghasilan menengah tinggi sebagian besar (83.3\%) telah menggunakan KB.

KB Tubektomi (MOW) adalah suatu kontrasepsi permanen dilakukan dengan tindakan pada kedua saluran sel telur. Cara kontrasepsi ini dipersiapkan melalui tindakan operasi kecil dengan cara mengikat atau memotong saluran telur atau tuba pada istri. (Saifudin, 2016).

Menurut BKKBN (20214) istri yang memilih KB Tubektomi adalah istri dari pasangan usia subur dengan syarat sebagai berikut: tidak ingin punya anak lagi; sukarela dan mendapat konseling tentang tubektomi; mendapat persetujuan dari suami; jumlah anak sudah ideal, sehat jasmani dan rohani; umur istri sekurang-kurangnya 25 tahun; mengetahui prosedur tubektomi dan akibatnya; menandatangani formulir persetujuan (informed consent).

Gambaran Faktor-faktor Yang Mempengaruhi Suami dalam memberikan dukukungan KB Tubektomi pada Istri di Desa Baturejo Kecamatan Sukolilo Kabupaten Pati Tahun 2020 adalah: pengetahuan, pendidikan, usia, jumlah anak, sikap, sosial budaya, pekerjaan. Penelitian dilakukan terhadap 34 responden.

Hasil penelitian menunjukkan bahwa semua responden berjumlah 34 orang memilih KB Tubektomi pada istri. Salah satu pertimbangan KB Tubektomi (MOW) adalah tingkat pengetahuan yang tinggi dalam pemilihan KB Tubektomi sangat mempengaruhi. Tingkat pendidikan, tingkat Usia Semakin bertambahnya usia, kebutuhan hidup bertambah banyak. Kemampuan mencukupi kebutuhan rumah tangga mulai menurun.

Pengalaman menghidupi keluarga, memenuhi kebutuhan anak dan istri, didukung oleh kesepakatan dengan istri membuat suami harus membuat keputusan jumlah anak. Keluarga yang sudah memiliki 2-5 orang anak mengambil langkah memilih KB Tubektomi.

Hal ini dilakukan karena mendapat dukungan dari pihak suami. yang 
mengatakan bahwa beratnya beban dan tanggung jawab menghidupi keluarga, perencanaan pendidikan anak dan masa depan keluarga. Dalam bersosial dan budaya respoden tidak begitu berpengaru terhadap pemilihan KB Tubektomi pada Istri dan pendapatan yang berbeda-beda tidak mempengaruhi responden menentukan sikap yaitu KB Tubektomi pada Istri. Berdasarkan hasil penelitian di Desa Kedungwinong Kecamatan Sukolilo Kabupaten Pati Tahun 2020, kesimpulan yang diperoleh yaitu Gambaran Faktorfaktor yang Mempengaruhi Suami dalam Memberikan Dukungan KB Tubektomi pada Istri di Desa Baturejo Kecamatan Sukolilo Kabupaten Pati Tahun 2020.

\section{SIMPULAN DAN SARAN}

Hasil penelitian menunjukkan hasil bahwa seluruh responden berjumlah 34 orang tingkat pengetahuan responden mengenai metode kontrasepsi MOW baik yaitu sebesar (58,82\%), tingkat pengetahuan cukup $(35,293 \%)$, tingkat pengetahuan kurang $(5,88 \%)$, Pendidikan responden sebagian besar SMA/MA/sederajat yaitu sebesar $44,12 \%$, yang tidak tamat SD sebesar sedangkan yang tamat SMA/MTs sebesar 29,41\%, $(8,82 \%)$, berpendidikan SD ada $(14,70 \%)$, dan berpendidikan Perguruan Tinggi ada $(2,94 \%)$., Sebagian besar responden $(47,05 \%)$ berumur $41-50$ tahun, yang ber umur 30-40 tahun sebesar $23,5 \%$, dan umur 51-60 tahun sebesar 29,4\%, responden memiliki anak 2-5 ada sejumlah $(52,94 \%)$, $>5$ anak ada sejumlah $(47,06 \%)$, sikap responden tentang KB Tubektomi pada Istri ada 2 yaitu responden bersikap positif sebesar $(88,23 \%)$, yang bersikap negatif $(11,77 \%)$, sebagian besar responden swasta sejumlah $(32,35 \%)$, yang bekerja sebagai petani sebanyak $(17,6 \%)$, sama halnya aynag bekerja sebagai PNS $(17,6 \%)$ dan bekerja sebagai buruh sejumlah $(8,82 \%)$, Sebagian besar memiliki sosial budaya kurang mendukung $(55,88 \%)$, sosial budaya mendukung sebesar $29,41 \%$. Sosial budaya tidak mendukung menduduki jumlah paling sedikit yaitu $14,71 \%$.

Penting bagi petugas kesehatan diharapkan lebih meningkatkan pelaksanaan Komunikasi, Informasi, Edukasi (KIE) mengenai kontrasepsi, tujuan, manfaat, indikasi, kontra indikasi dan macammacam metode kontrasepsi karena tingkat sosial budaya yang tidak mendukung masyarakat masih cukup tinggi $(29,41 \%)$.

\section{DAFTAR PUSTAKA}

Anggraini, Y. (2012). Pelayanan Keluarga Berencana.Yogyakarta: Rohima Press. BKKBN. (2011).

BKKBN, 2013. Layanan KB. Keluarga Indonesia yang Lebih Sehat \& Sejahtera. Jakarta.

BKKBN. 2017. Pencapaian Peserta KB Tahun 2017. www. BKKBN. go.id.

Depkes RI. 2012. Pedoman Penanggulangan Efek Samping / Komplikasi Kontrasepsi. Jakarta: Depkes RI.

Dewi, K. (2013). Kesehatan Reproduksi Dan Keluarga Berencana. jakarta: CV. Trans Info Media.

Endang Purwoastuti, E. S. W. (2015). Kesehatan Reproduksi dan Keluarga Berencana. Yogyakarta: Pustaka Baru Press.

Fitra Sawiyya Sufiati. 2011. Faktor Faktor Yang Berhubungan Dengan Pemilihan Metode Kontrasepsi Tubektomi Pada Pasangan Usia Subur. Jurnal Mahasiswa dan Peneliti Kesehatan. Prodi Ilmu Kesehatan Masyarakat.

url:

http://digilib2.unisayogya.ac.id/bitstream/ handle/123456789/602/FULL_TEKS_SK RIPSI_EFI_TRIMURYANI_181010435 4_PRODI\%20KEBIDANAN\%20PROG RAM\%20SARJANA\%20TERAPAN.pdf ?sequence $=1$ \&isAllowed $=y$

Garg, R., Shyamsunder, D., Singh, T., \& Avtar, P. (2010). Health And Population : Perspectives And Issues [ Incorporating Nihae Bulletin ( Estd . 1968 ) And The Journal Of Population Research ( Estd . 1974 )] Volume 33 Editorial : Role Of 
Hartanto, Hanafi. 2013. KB (Keluarga Berencana) dan Kontrasepsi. Jakarta: Pustaka Sinar harapan.

IBI. 2014. Bidan Menyongsong Masa Depan. Jakarta: PP IBI.

Notoatmodjo, Soekidjo. 2015. Pengantar Pendidikan Kesehatan dan Ilmu Perilaku Kesehatan. Yogyakarta: Andi Offset.

Notoatmodjo, Soekodjo. 2015. Metodologi Penelitian Kesehatan. Jakarta: Rineka Cipta.

Nurul Hidayah. 2019. Hubungan Pengetahuan dan Dukungan Suami Terhadap Pemilihan Kontrasepsi Tubektomi. Jurnal Endurance: Kajian Ilmiah Problema Kesehatan. E-ISSN - 2477-6521 Vol 4(1) Februari 2019 (421-428). Akademi Kebidanan Sempena Negeri. Url: https://www.researchgate.net/publication/ 334468281_Hubungan_Pengetahuan_dan _Dukungan_Suami_Terhadap_Pemilihan _Kontrasepsi_Tubektomi.

Nursalam. 2013. Konsep dan Penerapan Metodologi Penelitian Ilmu Keperawatan. Jakarta: Salemba Medika.

Nurul Farahan.2016. Gambaran Tingkat Pengetahuan Penggunaan Alat Kontrasepsi Pada Wanita Usia Subur Dan Dukungan Petugas Di Desa Bebandem Kabupaten Karangasem Bali Tahun 2014. ISSN: 2303-1395 E-JURNAL MEDIKA, VOL. 5 NO.4, APRIL, 2016. Program Studi Pendidikan Dokter, Fakultas Kedokteran Universitas Udayana. url: http://ojs.unud.ac.id/index/php.eum

Rosnitje Mangeto. 2019. Gambaran Pengetahuan, Sikap Dan Tindakan Akseptor $\mathrm{Kb}$ Terhadap Tindakan Tubektomi Di Puskesmas Kassi-Kassi Makassar Tahun 2019. Jurnal Farmasi Sandi Karsa Volume 5, Nomor 1. p-ISSN : 2461-0496. Akademi Kebidanan Sandi Karsa Makassar. Program Studi D-III Kebidanan Sandi Karsa Makassar. url: https://media.neliti.com/media/publicatio ns/286104-gambaran-pengetahuan-sikapdan-tindakan-86259e16.pdf.

Saifudin AB. 2013. Buku Panduan Praktis
Pelayanan Kontrasepsi Edisi I. Jakarta Penerbit Yayasan Bina Pustaka.

Sarwono Prawirohardjo. 2013. Buku Panduan Praktis Pelayanan Kotrasepsi. Jakarta : Yayasan Bina Pustaka Sarwono Prawirohardjo.

Seto, Dhini Hariyo, Saryono dan Ning Iswati. 2011. Faktor-Faktor Yang Mempengaruhi Minat Wanita Usia Subur Memilih Metode Kontrasepsi MOW Di Desa Butuh. Jurnal Kesehatan Keperawatan. Volume 7 (Nomor. 2). STIKES Muhammadiyah Gombong.

Susi Ernawati. 2016. Faktor yang Memengaruhi Keluarga Berencana (KB) Pria dengan Paritisipasi Pria dalam Keluarga Berencana di Wilayah Kerja Puskesmas Sedayu II. Jurnal Ners dan Kebidanan Indonesia. ISSN2354-7642. Universitas Alma Ata Yogyakarta. url: http://ejournal.almaata.ac.id/index.php/J NKI

Sterilisasi Kurang Mendongkrak Penurunan Fertilitas. Retrieved from http://www.bkkbn.go.id/litbang/pusna /data/Policybrief1\%5BI\%5D.PDF BPS. (2013). Survey Demografi Kesehatan Indonesia 2012. Jakarta.

Tim Penyusun Kamus Besar Bahasa Indonesia. 2013. Kamus Besar Bahasa Indonesia Ediasi III. Jakarta: Balai Pustaka

UPTD PPI DAN KB Kecamatan Kradenan, 2018. Laporan Tahunan KB, Kradenan: UPTD PPI DAN KB Kecamatan Kradenan.

Vida Wira Utami1. 2014. Faktor - Faktor Yang Mempengaruhi Penggunaan Vasektomi Di Kota Bandar Lampung. Jurnal Kesehatan Holistik. Vol 8, No 3, Juli 2014 : 115-119. Prodi Kebidanan FK Universitas Malahayati B. Lampung.

url:

http://ejurnalmalahayati.ac.id/index.php/h olistik/article/download/150/92.

Wiknjosastro, Hanifa. 2014. Ilmu Kandungan. Edisi II. Jakarta: Yayasan Bina Pustaka Sarwono Prawiroharjo.

.2002. Seri Booklet Kontrasepsi Pria. Jakarta: BKKBN. 
.Panduan Pelayanan Vasektomi Tanpa Pisau. Jakarta: PKMI.

Yuli Suryanti. 2019. Faktor- Faktor Yang Berhubungan Dengan Penggunaan Metode Kontrasepsi Jangka Panjang Wanita Usia Subur. Jambur Journal. Vol.1 No.1. Januari 2019. Jurusan Kebidanan, Poltekkes Kemenkes, Jambi. url:

http://ejournal.ung.ac.id/index.php//jjhsr. Buku Ajar Keperawatan Maternitas, Edisi 4, EGC. Jakarta

Keliat, 2010. Keperawatan Jiwa: Konsep dan Klinis, EGC, Jakarta

Kusmiyati, Wahyuningsih, Sujiyatini. 2015. Perawatan Ibu Hamil. Fitramaya. Bandung

M.Nazir, 2011, Metode Penelitian, Ghalia Indonesia

Manuaba, 2015. Memahami Kesehatan reproduksi Wanita. Arcan. Jakarta

Notoatmodjo, Soekidjo, 2012, Metodologi Penelitian Kesehatan, Rineka Cipta, Jakarta

Nursalam, 2010, Konsep Dan Penerapan Metodologi Penelitian Ilmu
Keperawatan, Salemba Medika, Jakarta Pangkahila, Wimpie, 2011, Mitos Seks Pun

Melingkupi Kehamilan, www.yahoo.com Stuart dan Sundeen, 2013. Keperawatan Jiwa. EGC, Jakarta

Sugiyono, 2010, Metodologi Penelitian Administrasi Edisi 13, Alfa Beta, Bandung

Sugiyono, 2010, Statistik Penelilian Edisi 5, Alfa Beta, Bandung Universitas Bandung, Binarupa Aksara, Jakarta

Syaifudin. 2011. Buku Panduan Praktis Pelayanan Kontrasespsi, Yayasan Bina Pustaka Sarwono Prawiroharjo, Jakarta

UNDP. 2019. Laporan Perkembangan Pencapaian Tujuan Pembangunan Indonesia Millenium. http://www.undp.org.id/pubs/imdg2004/ BI/indonesia MDG-BI/goall-pdf

Wikepedia,2014, Hubungan Sexual, http://id.wikipedia.org/wiki/Hubungan_seksual 